\title{
Studi Pakan Burung Perkici Pelangi (Trichoglossus haematodus Linnaeus, 1771) dalam Laboratorium Penangkaran
}

\author{
Study on Food Rations of the Rainbow Lorikeet (Trichoglossus haematodus Linnaeus, \\ 1771) in the Animal House Laboratory
}

\section{W. Widodo}

Bidang Zoologi, Pusat Penelitian Biologi LIPI, Jln Raya Jakarta-Bogor KM46 Cibinong 16911

E-mail: wiedodo_318170@yahoo.com

\begin{abstract}
During the 2002-2003 period, the research was done to study 11 Rainbow Lorikeets reared in an animal house laboratory. The aim of this research was to find the food rations formule of the Rainbow Lorikeets so that those birds can be able to grow and breed well. The food rations were composed of $26.3 \%$ local bird foods (521), 35.09\% lampung bananas, $8.77 \%$ slice corns, $10.5 \%$ boiled quails eggs, $1.75 \%$ white bread, bean sprouts and red sugar are $8.77 \%$, respectively. All of food materials were mixed on the plastic cup and mixed with $450 \mathrm{ml}$ of water, then pulverized like sweet porridge. That porridge was given to birds in cafeteria and the water was made ready "ad libitum" everyday. The results have shown that giving food rations formula can stimulate two pairs of the Rainbow Lorikeets breeding and during the 2002-2003 period they produced three young birds.
\end{abstract}

Key words: food rations, Trichoglossus haematodus, breeding captivity

Diterima: 10 Agustus 2005, disetujui: 12 Mei 2006

\section{Pendahuluan}

Perkici pelangi (Trichoglossus haematodus Linnaeus, 1771) adalah burung paruh bengkok dari suku Psittacidae yang tersebar luas di Kepulauan Maluku dan Papua (Coates et al., 1997; Juniper and Parr, 1998). Sebagai anggota kelompok burung nuri-nurian, perkici pelangi cukup menarik dengan ragam warna bulu-bulu sangat indah (eksotik) dan suaranya merdu serta pintar bicara kalau dipelihara sejak kecil dan rajin diajari menirukan suara-suara pemiliknya. Harga perkici pelangi di pasaran JABOTABEK tahun 1999/2000 berkisar antara Rp 40.000,- s/d Rp 100.000,- per ekor (Widodo, 2002) dan di pasar-pasar burung di Bali antara Rp 100.000,s/d 175.000,- per ekor (Widodo, 2005).

Burung perkici pelangi semakin marak diperdagangkan di berbagai pasar burung di dalam negeri atau pun ekspor. Agar burung ini tidak berkurang atau punah populasinya seperti burung gelatik dan elang (Laudensius et al., 2000), maka perlu diupayakan penangkaran. Faktor penting agar burung dapat berbiak harus diketahui pakan pilihan, jumlah yang dimakan dan waktu makan (Mardiastuti et al., 2000).

Pakan perkici pelangi di dalam laboratorium penangkaran tentu amat berbeda dengan sewaktu masih hidup di alam. Bell (1966) menyatakan bahwa beberapa macam kebiasaan makan marga Trichoglossus sp. di alam adalah pemakan nektar dan buah-buahan. Walaupun, T. haematodus dilaporkan pula mampu eksis di penangkaran makan biji-bijian dan juga ulat. Rose (1997) menambahkan bahwa T. haematodus makan pada bungabunga Eucalyptus, Grevillea, Callistemon, Banksia, Camellia, Bauhinia dan bunga dari kayu payung (Schefflera actinophylla). Di Taman Nasional Manusela, Seram, Maluku Tengah dijumpai bahwa perkici pelangi 
memakan nektar bunga jalitri-jalitrian (Elaeocarpus sphaericus) dan kayu putih (Eucalyptus deglupta) (Widodo, 2006).

Dalam studi perkici pelangi di laboratorium penangkaran, faktor preferensi pakan dan jumlahnya pakan yang dikonsumsi sangat penting untuk diketahui, karena harus mendukung upaya keberhasilan burung dapat berbiak "breeding". Untuk mencapai tujuan tersebut penelitian dilakukan dalam dua tahap:

(1).Dengan cara memberikan bermacammacam bahan pakan yang mudah didapat di pasaran dan dengan harga relatif murah pula. Di antaranya adalah campuran beberapa bahan pakan seperti pisang lampung, pur burung 521 lokal, roti tawar dan sayur-sayuran. Tujuannya untuk mengetahui jumlah konsumsi ransum bahan pakan terpilih bagi burung perkici di penangkaran. Diharapkan diperoleh formulasi ransum dasar untuk pengembangbiakan perkici pelangi secara $e x$-situ.

(2).Dengan cara memberikan peningkatan protein hewani ke dalam ransum perkici pelangi yang ditangkarkan. Tujuannya adalah memacu proses "breeding". Hasil yang diharapkan adalah bermanfaat untuk meningkatkan kemampuan reproduksi perkici pelangi dalam penangkaran.

Dari seluruh hasil penelitian di atas, selanjutnya diharapkan dapat direkomendasikan sebuah studi lebih detail tentang pengaruh kandungan protein hewani dalam komposisi pakan perkici pelangi terhadap kemampuan berkembangbiaknya di dalam penangkaran.

\section{Metode Penelitian}

Studi tentang pakan perkici pelangi dilakukan di Laboratorium Penangkaran Puslit Biologi LIPI, unit zoologi Cibinong, dalam kurun waktu tahun 2002-2003. Materi yang digunakan dalam penelitian adalah 11 eko perkici pelangi dewasa yang dibeli dari pasa burung Pramuka, Jakarta.

Penelitian dilaksanakan dalam dua tahap yaitu:

Tahap I: untuk mengetahui ada tidakny perbedaan preferensi pakan dan jumla konsumsi makan burung-burung perkic pelangi yang diberi ransum dasar, di antarany dengan salah satu bahannya terdiri dari pu burung 521 lokal beraroma pisang dan yan tidak beraroma pisang. Bahan-bahan ransun yang disediakan untuk perlakuan P1 dan P dalam dua ruangan kandang dapat dilihat pad Tabel 1. Caranya: 11 ekor perkici pelang dikandangkan dalam dua ruangan kandan kawat "bank" (loket), masing-masin berukuran $\mathrm{p}$ x 1 x t: 3,32 m x 1,82 m x 2,85 m Di tengah-tengah dinding kawat penyekat $\mathrm{c}$ antara dua ruangan kandang, dipasang sebua pintu (pxl=60 cm x $60 \mathrm{~cm}$ ) yang selalu dibuka sehingga kesempatan burung-burung perkic pelangi dapat terbang leluasa untuk makan dar kandang satu ke kandang dua adalah sama da sebaliknya. Kondisi lingkungan dan sarana d kandang satu dan dua relatif sama. Hewa pengganggu seperti tikus dan tokek dicegal dengan cara menutup celah di sudut-sudu ruangan kandang 1.

Prosedur pembuatan ransum pakal perkici pelangi dari percobaan di atas adala sebagai berikut: semua bahan pakan pad perlakuan P1 dan P2, ditempatkan ke dalan mangkuk plastik yang berbeda, lal ditambahkan air, masing-masing sebanyak 25 ml. Selanjutnya, semua bahan pakan pad mangkuk pertama ditumbuk secara manua dengan alat tumbuk dari kayu dan diadul sampai merata, sehingga tekstur bahan paka berbentuk lunak/lembek seperti bubur. Begit pula, semua bahan pakan pada perlakuan $\mathrm{P}$ dilakukan sama seperti pada perlakuan P1.

Tabel 1. Macam dan jumlah bahan pakan yang diberikan pada 11 ekor perkici pelangi (T. haematodus) dalar penelitian tahap I

\begin{tabular}{|c|c|c|c|}
\hline \multicolumn{2}{|c|}{ Perlakuan 1} & \multicolumn{2}{|l|}{ Perlakuan 2} \\
\hline Macam bahan pakan & Jumlah Pemberian (g) & Macam bahan pakan & Jumlah Pemberian $(\mathrm{g}$ \\
\hline Pur burung 521 beraroma pisang & 100 & Pur burung 521 tidak beraroma pisang & 100 \\
\hline Pisang lampung & 150 & Pisang lampung & 150 \\
\hline Roti tawar & 11,45 & Roti tawar & 10,75 \\
\hline Telur puyuh rebus & 8,0 & Telur puyuh rebus & 7,90 \\
\hline Taoge & 19,30 & Taoge & 19,30 \\
\hline
\end{tabular}


Selanjutnya, campuran bahan-bahan pakan pada perlakuan P1 dibagi ke beberapa baki plastik berukuran pxl: $20 \mathrm{~cm}$ x $20 \mathrm{~cm}$ dan dimasukkan ke ruangan kandang satu. Sedangkan, campuran bahan-bahan pakan pada perlakuan P2 dimasukkan ke ruangan kandang dua. Frekuensi pemberian pakan setiap hari hanya diberikan pada pagi hari (pukul 08.00) dan secara kafetaria. Air minum diberikan secara ad libitum.

Dasar pertimbangan pemberian pakan perkici pelangi seperti perlakuan $\mathrm{P} 1$ dan $\mathrm{P} 2$ di atas adalah memodifikasi cara Handini dan Astuti (1999), yang menyatakan bahwa burung-burung perkici pelangi dapat menerima dan beradaptasi dengan pakan campuran yang berbentuk bubur.

Sisa-sisa pakan yang tidak termakan dikumpulkan, lalu ditimbang dengan timbangan Pesola kepekaan 0,01 dan dihitung jumlah pakan yang dikonsumsi dengan cara: pengurangan bahan pakan yang diberikan dengan sisa pakan yang tersisa/tidak dimakan.

Tahap II: bertujuan untuk mengetahui apakah dengan peningkatan pemberian protein hewani dapat memacu perkembangbiakan (reproduksi)perkici pelangi dalam laboratorium penangkaran. Caranya: 11 ekor perkici pelangi dibagi ke dalam dua kelompok, $A=9$ ekor (terdiri 4 jantan +5 betina) dan $\mathrm{B}=2$ ekor (terdiri satu pasang). Kedua kelompok perkici pelangi tersebut lalu dikandangkan ke dalam dua ruangan kandang yang berukuran sama seperti pada penelitian tahap pertama. Namun, di antara dua ruang kandang tidak dihubungkan dengan pintu terbuka, sehingga burung-burung pada kelompok A tidak dapat berpindah ke ruang kandang B atau sebaliknya. Macam dari bahan pakan yang diberikan untuk kedua kelompok burung yang diamati adalah sama. Namun, pada tahap II penelitian ditambahkan jagung iris segar dan gula merah. Fungsi jagung iris untuk menambah sumber energi dalam ransum, sedangkan gula merah berfungsi sebagai penambah cita rasa. Pemberian telur puyuh rebus ditingkatkan dari 10 gram/hari menjadi 60 gram/hari. Jumlah air yang ditambahkan ke dalam campuran bahan pakan pada penelitian tahap II adalah $450 \mathrm{ml}$. Prosedur pembuatan pakan campuran hingga berbentuk bubur sama seperti pada penelitian tahap I. Selanjutnya, macam dan proporsi bahan pakan dalam ransum penelitian tahap II dapat dilihat pada Tabel 2.

Kandungan nutrisi dari ransum pakan perkici pelangi yang diberikan dalam penelitian tahap II dapat dilihat seperti pada Tabel 3.

Tabel 2. Macam dan jumlah bahan pakan yang diberikan pada kedua kelompok perkici pelangi (T. haematodus) rata-rata tiap hari pada penelitian tahap II

\begin{tabular}{clcc}
\hline \hline No. & \multicolumn{1}{c}{ Macam bahan pakan } & Jumlah pemberian (g) & \% pemberian \\
\hline \hline 1 & Pur burung 521 tidak beraroma pisang & 150 & 26,32 \\
2 & Pisang lampung & 200 & 35,09 \\
3 & Jagung iris & 50 & 8,77 \\
4 & Roti tawar & 10 & 1,75 \\
5 & Telur puyuh rebus & 60 & 10,53 \\
6 & Taoge & 50 & 8,77 \\
7 & Gula merah & 50 & 8,77 \\
\hline & TOTAL & 570 & 100,00 \\
\hline \hline
\end{tabular}

Tabel 3. Kandungan nutrisi dari ransum pakan perkici pelangi (T. haematodus) dalam penelitian tahap II (*)

\begin{tabular}{|c|c|c|c|c|c|c|c|}
\hline No. & Bahan pakan & PK (\%) & Lemak (\%) & SK (\%) & Ca (\%) & $\mathbf{P} \mathbf{P}(\%)$ & EM (Kcal/kg) \\
\hline 1 & Pur burung 521 beraroma pisang & 12,93 & ב5,42 & 13,69 & 1,18 & 0,98 & 4135 \\
\hline 2 & Pur burung 521 tidak beraroma pisang & 13,29 & 5,07 & 13,12 & 1,28 & 0,93 & 3861 \\
\hline 3 & Pisang lampung & 1,34 & 0,11 & 0,05 & 0,04 & 0,03 & 1074 \\
\hline 4 & Roti tawar & 8,48 & 3,05 & 0,25 & 0,09 & 0,12 & 2676 \\
\hline 5 & Telur puyuh rebus & 16,54 & 6,54 & 0,02 & 0,34 & 0,37 & 3858 \\
\hline 6 & Taoge & 7,59 & 0,35 & 2,10 & 0,03 & 0,13 & 1235 \\
\hline 7 & Jagung iris & 9,85 & 4,24 & 1,93 & 0,05 & 0,34 & 4152 \\
\hline 8 & Gula merah & 1,27 & 0,75 & 0,14 & 0,38 & 0,12 & 1239 \\
\hline
\end{tabular}

Keterangan: *)= Nilai nutrisi sesuai hasil analisis kimiawi yang dilakukan di Lab. Ilmu dan Teknologi Pakan, Fak. Peternakan IPB Darmaga (Bogor). PK=protein kasar, SK=serat kasar, EM=energi metabolis 


\section{Analisis Data}

Data konsumsi pakan perkici pelangi pada masing-masing perlakuan (P-1 dan P-2) pada penelitian tahap I dianalisis menggunakan uji T (Riduwan, 2003). Sedangkan untuk menghitung nilai protein dalam ransum penelitian tahap II digunakan metode Bujur Sangkar Pearson mengikuti Nawawi dan Nurahmah (2003).

\section{Hasil dan Pembahasan}

\section{Tahap I}

Hasil percobaan tahap I menunjukkan, bahwa baik ransum perlakuan P1 maupun P2 yang pemberiannya dalam bentuk bubur telah dapat diterima secara baik oleh 11 ekor perkici pelangi yang diteliti. Rata-rata jumlah konsumsi pakan perkici pelangi dengan pemberian ransum $\mathrm{P} 1$ adalah $37,55 \pm 3,42$ gram/ekor/hari dan dengan pemberian ransum P2 adalah 38,46 $\pm 3,90$ gram/ekor/hari. Konsumsi pakan perkici pelangi secara detail dapat dilihat pada Tabel 4.

Pada Tabel 4 tampak bahwa rataan konsumsi pakan perkici pelangi per ekor per hari dengan ransum $\mathrm{P} 1$ cenderung lebih sedikit dibandingkan ransum P2. Berdasarkan uji " $t$ " ternyata tidak menunjukkan perbedaan secar nyata. Dari hasil tersebut dapat diketahui bahwa konsumsi pakan burung perkici pelang menggunakan pur burung 521 tidak berarom pisang tidak memberikan perbedaan secar nyata bila dibandingkan dengan pemberia ransum menggunakan pur burung 52 beraroma pisang. Dengan demikian, jumla konsumsi pakan perkici pelangi yang diteliti d laboratorium penangkaran tidak dipengaruh oleh aroma pakan. Hal ini agak berbeda denga pendapat Parakkasi (1990) yang menyataka bahwa sesungguhnya palatabilitas merupaka faktor sangat penting untuk menentuka tingkat konsumsi pakan, karena palatabilita pakan ditentukan oleh rasa, bau dan warna Dari hasil penelitian, tampaknya konsums pakan lebih dipengaruhi oleh rasa manis pisan lampung dan tekstur pakan yang lunak. Hal in disebabkan burung-burung perkici pelang mempunyai struktur lidah yang di bagia ujungnya seperti sikat yang biasanya berfungs untuk menghisap rasa manis madu bunga ata polen dari suatu tumbuhan. Sesuai Prijon (1994) bahwa kesukaan burung untuk memili] suatu jenis pakan dipengaruhi oleh tekstu makanan, ukuran dan juga sifat-sifat dar individu burung tersebut serta jenis pakan ap yang biasa dimakannya.

Tabel 4. Konsumsi pakan perkici pelangi (T. haematodus) dengan ransum percobaan P1 dan P2 (gram/ekor/hari)

\begin{tabular}{ccc}
\hline \hline \multirow{2}{*}{ Ulangan } & \multicolumn{2}{c}{$\sum$ konsumsi pakan (gram/ekor/hari) } \\
\cline { 2 - 3 } & Ransum P1 & Ransum P2 \\
\hline \hline 1 & 36,36 & 36,36 \\
3 & 33,64 & 36,36 \\
4 & 38,18 & 38,18 \\
5 & 38,18 & 40,0 \\
6 & 39,09 & 36,36 \\
7 & 38,18 & 37,37 \\
8 & 33,64 & 36,36 \\
9 & 40,91 & 40,90 \\
10 & 40,0 & 48,18 \\
Rataan \pm SD & 37,37 & 34,54 \\
Kisaran & $37,55 \pm 3,42$ & $38,46 \pm 3,90$ \\
\hline \hline Keterangan: & $33,64-40,91$ & $34,54-48,18$ \\
\hline
\end{tabular}

Keterangan: P1 = menggunakan pur burung 521 beraroma pisang dan P2 = menggunakan pur burung 521 tidal beraroma pisang 
Bila ditinjau kembali besarnya jumlah konsumsi pakan perkici pelangi dari hasil penelitian, baik pada perlakuan P1 dan P2, tak jauh berbeda dengan jumlah konsumsi pakan harian yang diberikan untuk jenis-jenis lorikeet, termasuk $T$. haematodus yang disampaikan oleh Lint \& Lint (1981). Menurut Lint \& Lint (1981), pakan harian $T$. haematodus juga sebanyak 38 gram/ekor/hari. Walaupun, proporsi dan macam pakan sedikit berbeda, yaitu terdiri dari: 14 gram buahbuahan, 5 gram roti tawar, 5 gram susu kental manis, 2 gram sirup santan, 2 gram parutan wortel dan slada, 2 gram mineral dan 3 gram vitamin.

Bila dibandingkan dengan berat badan perkici pelangi yang diteliti, yang dapat mencapai kisaran 150 gram (Forshaw and Cooper, 1989), maka konsumsi pakan perkici pelangi dengan ransum pakan P1 adalah antara 22,75-27,31\% dan bila menggunakan perlakuan P2 adalah antara 23,04-28,24\%, dari total berat badannya. Dengan memperhatikan perbandingan konsumsi pakan dan berat badan perkici pelangi percobaan, maka konsumsi pakan perkici pelangi tersebut dapat dikatakan masih cukup normal. Bagi "song birds" (burung-burung berkicau) yang berat badannya antara 10-90 gram, konsumsi makannya adalah 10-30\% dari berat badannya per hari (VanTyne and Berger, 1976).

\section{Tahap II}

Pada penelitian tahap II, komposisi bahan pakan yang diberikan terhadap perkici pelangi adalah ransum dasar perlakuan P2, yang salah satu di antaranya menggunakan pur burung 521 tidak beraroma pisang. Dengan dasar pertimbangan, sumber bahan pakan tersebut adalah lebih mudah didapatkan di pasaran.dan tidak menunjukkan perbedaan secara nyata dengan perlakuan P1. Dengan menggunakan rumus "Bujur Sangkar Pearson", ternyata nilai protein dari ransum P2 adalah $11,45 \%$. Nilai protein tersebut sesuai dengan yang diberlakukan pada pemberian pakan hewan-hewan monogastrik, termasuk bangsa unggas/burung (Parakkasi, 1990). Namun demikian, berdasarkan pengamatan ternyata kandungan protein dalam ransum P2 tersebut baru untuk memenuhi kebutuhan pokok dan belum dapat memberikan pengaruh terhadap seksual/terjadinya breeding pada perkici pelangi yang diteliti. Sehingga, dalam penelitian tahap II sumber protein hewani komposisi ransum P2 ditingkatkan jumlahnya, terutama kuantitas telur puyuh rebus. Selain itu ditambahkan beberapa macam bahan pakan tambahan seperti jagung iris sebagai sumber energi (lihat Tabel 2).

Hasil pengamatan menunjukkan bahwa peningkatan pemberian beberapa bahan pakan dalam ransum perkici pelangi, terutama penambahan telur puyuh rebus dari 10 gram $(2,8 \%)$ menjadi 60 gram $(10,53 \%)$ dari total ransum, telah memberikan hasil positif. Komponen tersebut dapat merangsang aktifitas "breeding" perkici pelangi dalam penelitian. Di antara pasangan perkici pelangi dalam kelompok A mulai mengetengahkan gerakangerakan perkawinan. Hal ini, diawali dengan sang jantan berjoget/menari-nari di sekitar betina pasangannya, sambil berusaha mencumbu ataupun berusaha menaikinya. Satu pasangan perkici pelangi dalam kelompok A yang telah berhasil melakukan perkawinan terjadi tanggal 13-8-2003. Selanjutnya, dalam periode penelitian tersebut pasangan perkici pelangi dari kelompok A telah menghasilkan dua anakan dan pasangan perkici pelangi dari kelompok B menghasilkan satu anakan.

Bila ditinjau menggunakan "metode bujur sangkar Pearson", kandungan protein dalam ransum perkici pelangi telah mengalami peningkatan dari $11,45 \%$ menjadi $17,5 \%$. Dari hasil tersebut menunjukkan bahwa peningkatan protein terutama protein hewani dalam suatu ransum pakan burung sangat diperlukan. Hal ini selain protein berfungsi untuk pertumbuhan, juga penting di dalam produksi dan reproduksi (Kartadisastra, 1994).

Dengan demikian, formulasi ransum yang diberikan pada pasangan perkici pelangi tersebut dapat dipakai sebagai acuan pendahuluan dalam suatu usaha budidaya/penangkaran bagi burung-burung pemakan nektar dari anggota suku Psittacidae, khususnya Trichoglossus haematodus. Hingga, nantinya dapat diketemukan formulasi yang baku pada penelitian-penelitian berikutnya. 


\section{Kesimpulan}

Dapat disimpulkan bahwa aroma pada ransum tidak berpengaruh terhadap konsumsi pakan perkici pelangi dalam labotarorium penangkaran. Pemberian pakan yang terdiri: 150 gram pur burung 521; 200 gram pisang lampung; 10 gram roti tawar; 50 gram jagung iris; 60 gram telur puyuh rebus; 50 gram gula merah; dan 50 gram toge ternyata dapat diterima dengan baik oleh 11 ekor perkici pelangi dalam penelitian. Ransum tersebut dapat memacu upaya perkembangbiakannya secara ex-situ.

\section{Daftar Pustaka}

Bell, H.L. 1966. Some Feeding Habits of the Rainbow Lorikeets. EMU 66: 71-72.

Coates, B.J., Bishop, K.D. and Gardner. 1997. A Guide to the Birds of Wallacea. Dove Publication, Australia.

Forshaw, F.M. and Cooper, W.T. 1989. Parrots of the World. $3^{\text {rd }}$. Ed. Lansdowne Editions, Australia.

Handini, S. and Astuti, D. 1999. Upaya Menangkarkan Burung Kasturi (Trichoglossus haematodus). Laptek 1998/1999 Proyek Litbang Pendayagunaan Biota Darat, Puslitbang Biologi LIPI, Bogor.

Juniper, T. and Parr, M. 1998. Parrots, A Guide to the Parrots of the World. Pica Press, Netherlands.

Kartadisastra, H.R. 1994. Pengelolaan Pakan Ayam, Kiat Meningkatkan Keuntungan dalam Agribisnis Unggas, Penerbit Kanisius, Yogyakarta.

Laudensius, O.F.X., Tusoro, T.A., Giri, S.A. and Yuda, I.P. 2000. Burung Gelatik Jawa (Padda oryzivora) di Yogyakarta. Biota V (1): 29-34.
Lint, K.C. and Lint, A.M. 1981. Diets for Birds Captivity. Bland Ford Press, United Kingdom

Mardiastuti, A., La Ode, R.S. and Yeni, A.M. 2000 Pemilihan Tempat dan Waktu Makan ole Satwa Frugifora pada Pohon Ficus di Suak Margasatwa Lambusongo, Buton. Biota (1): 22-28.

Nawawi, T. and Nurahmah, S. 2003. Ransum Aya Kampung. Penebar Swadaya, Jakarta.

Parakkasi, A. 1990. Ilmu Gizi dan Makanan Terna Monogastrik. Penerbit Angkasa, Bandung.

Prijono, S.N. 1994. Burung Cacatua goffini dalar Populasi Campuran di Kandang Penangkarar Prosiding Sem. Has. Litbang SDH, Pusl Biologi LIPI. Bogor, 4 April 1994.

Riduwan. 2003. Dasar-dasar Statistika, Edisi Revis Alfabeta, Bandung.

Rose, A.B. 1997. Notes on the Diet of Some Parrots i New South Wales. Australian Bird Watche 17: 134-137.

Van-Tyne, J. and Berger, A.J. 1976. Fundamentals Ornithology. $2^{\text {nd }}$. John Wiley \& Sons, Ner York.

Widodo, W. 2002. Perdagangan Burung-burung Paru Bengkok (Suku Psittacidae) di JABOTABEK Makalah Seminar Nasional ke IX Persad Cab. Bogor, di F-MIPA IPB Baranangsiang Bogor.

Widodo, W. 2005. Perdagangan Burung-burung Paru Bengkok di Bali. Berk. Penel. Hayati 11 (1) 31-37.

Widodo, W. 2006. Kemelimpahan dan Sumber Paka Burung-burung di Taman Nasional Manusela Seram, Maluku Tengah. Biodiversitas 7 (1 54-58. 